Post-Closure Inspection and Monitoring Report for Corrective Action Unit 417:

Central Nevada Test Area Surface, Hot Creek Valley, Nevada

October 2009

Approved for public release; further dissemination is unlimited 
Available for sale to the public from:

U.S. Department of Commerce

National Technical Information Service

5301 Shawnee Road

Alexandria, VA 22312

Telephone: 800.553.6847

Fax: 703.605.6900

E-mail: orders@ntis.gov

Online Ordering: http://www.ntis.gov/help/ordermethods.aspx

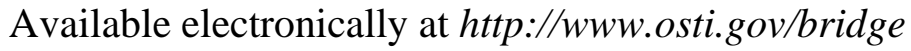

Available for a processing fee to U.S. Department of Energy and its contractors, in paper, from:

U.S. Department of Energy

Office of Scientific and Technical Information

P.O. Box 62

Oak Ridge, TN 37831-0062

Phone: 865.576.8401

Fax: 865.576.5728

Email: reports@adonis.osti.gov

Reference herein to any specific commercial product, process, or service by trade name, trademark, manufacturer, or otherwise, does not necessarily constitute or imply its endorsement, recommendation, or favoring by the United States Government or any agency thereof or its contractors or subcontractors. 


\section{Post-Closure Inspection and Monitoring Report for Corrective Action Unit 417: \\ Central Nevada Test Area Surface, Hot Creek Valley, Nevada}

October 2009 
This page intentionally left blank 


\section{Contents}

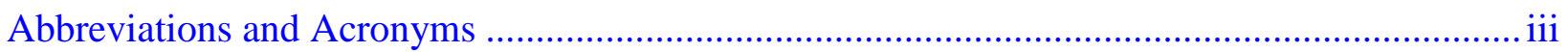

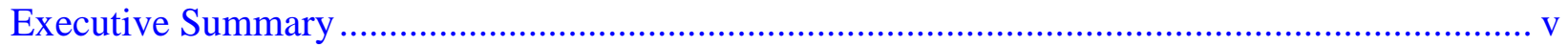

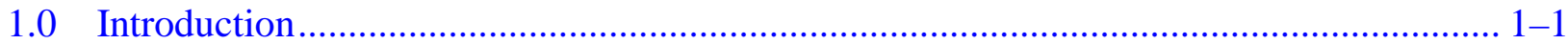

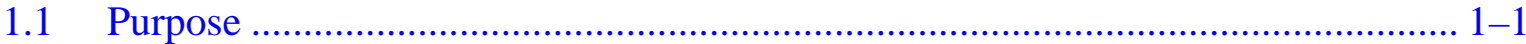

1.2 Site Location and Background....................................................................... 1-1

1.3 Geologic Setting ............................................................................................. 1-2

2.0 Post-Closure Monitoring Requirements ……………................................................. 2-1

$2.1 \quad$ Site Inspections .......................................................................................... 2-1

2.2 Maintenance and Repair ............................................................................... 2-1

2.3 Cover Moisture Monitoring .............................................................................. 2-2

2.4 Cover Moisture Compliance Criteria................................................................. 2-2

2.5 Reporting Requirements ............................................................................ 2-4

3.0 Site Inspections, Surveys, and Maintenance ................................................................. 3-1

3.1 Annual Site Inspection Results ................................................................. 3-1

3.1.1 UC-1 Inspection............................................................................... 3-1

3.1.2 UC-3 Inspection............................................................................. 3-1

3.1.3 UC-4 Inspection................................................................................ 3-1

3.2 Subsidence Survey Results ............................................................................. 3-1

3.2.1 UC-1 Survey ………………......................................................... 3-1

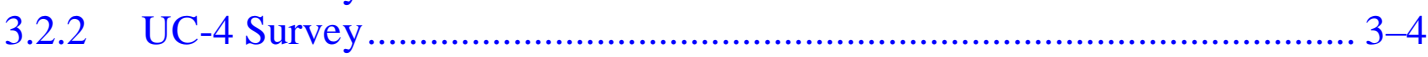

3.3 Vegetation Survey Results............................................................................ 3-4

3.4 Precipitation and Soil Moisture Monitoring Results ............................................... 3-6

3.4.1 UC-1 Soil Moisture Results................................................................. 3-6

4.0 Summary, Conclusions, and Recommendations............................................................ 4-1

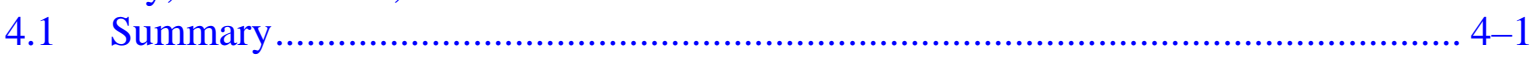

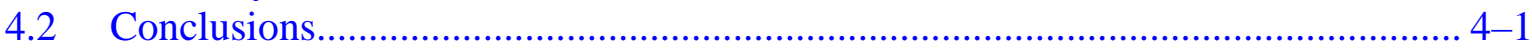

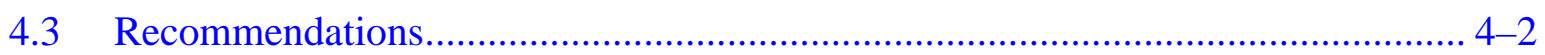

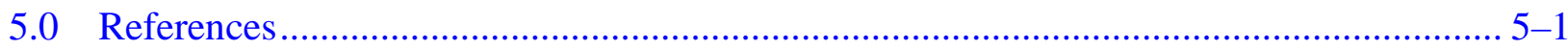

\section{Figures}

Figure 1-1. Central Nevada Test Area Location Map ..................................................... 1-2

Figure 1-2. CAU 417, Central Nevada Test Area Surface Map .............................................. 1-4

Figure 2-1. UC-1 CMP Cover Monitoring Instrumentation ....................................................... 2-3

Figure 3-1. Location of UC-1 Significant Features.......................................................... 3-2

Figure 3-2. Location of UC-3 Significant Features................................................................. 3-2

Figure 3-3. Location of UC-4 Significant Features............................................................ 3-3

Figure 3-4. UC-1 Cover Settlement …………............................................................. 3-3

Figure 3-5. UC-4 West and East Monuments ....................................................................... 3-5

Figure 3-6. UC-4 Cover Settlement ........................................................................... 3-6

Figure 3-7. July 1, 2008, through June 30, 2009, Precipitation Data......................................... 3-7

Figure 3-8. UC-1 Soil Moisture Content, East TDR Nest A...................................................... 3-7

Figure 3-9. UC-1 Soil Moisture Content, East TDR Nest B ..................................................... 3-8

Figure 3-10. UC-1 Soil Moisture Content, West TDR Nest A …………….............................. 3-8

Figure 3-11. UC-1 Soil Moisture Content, West TDR Nest B .................................................. 3-9 


\section{Appendixes}

Appendix A Inspection Checklists and Photographs

Appendix B Survey Data

Appendix C 2009 Revegetation Success Monitoring

Appendix D NDEP Correspondence and Record of Review 


\section{Abbreviations and Acronyms}

$\begin{array}{ll}\text { CAU } & \text { Corrective Action Unit } \\ \mathrm{cm} & \text { centimeter(s) } \\ \text { CMP } & \text { Central Mud Pit } \\ \text { CNTA } & \text { Central Nevada Test Area } \\ \text { LM } & \text { U.S. Department of Energy Office of Legacy Management } \\ \text { FFACO } & \text { Federal Facility Agreement and Consent Order } \\ \mathrm{ft} & \text { foot (feet) } \\ \text { km } & \text { kilometer(s) } \\ \mathrm{m} & \text { meter(s) } \\ \text { mi } & \text { mile(s) } \\ \text { NDEP } & \text { Nevada Division of Environmental Protection } \\ \text { SOARS } & \text { System Operation and Analysis at Remote Sites } \\ \text { SM } & \text { Subsidence monument } \\ \text { TDR } & \text { Time domain reflectometry } \\ \text { VMC } & \text { Volumetric moisture content }\end{array}$


This page intentionally left blank

Page iv 


\section{Executive Summary}

This report presents results of data collected during the annual post-closure site inspection conducted at the Central Nevada Test Area, surface Corrective Action Unit (CAU) 417 in June 2009. The annual post-closure site inspection included inspections of the UC-1, UC-3, and UC-4 sites in accordance with the Post-Closure Monitoring Plan provided in the CAU 417 Closure Report (NNSA/NV 2001).

The annual inspection conducted at the UC-1 Central Mud Pit (CMP) indicated that the site and soil cover were in good condition. Three new fractures were identified in the soil cover and were filled with bentonite chips during the inspection. The vegetation on the soil cover was adequate but showed signs of the area's ongoing drought. No issues were identified with the CMP fence, gate, or subsidence monuments. No issues were identified with the warning signs and monuments at the other two UC-1 locations.

The annual subsidence survey was conducted at UC-1 CMP and UC-4 Mud Pit C in June 2009. The results of the subsidence surveys indicate that the covers are performing as expected, and no unusual subsidence was observed. However, the two UC-4 subsidence markers have shown increases in elevation over the past year.

A vegetation survey of the UC-1 CMP cover and adjacent areas was conducted as part of the annual inspection. The vegetation survey indicated that revegetation continues to be successful. The vegetation should continue to be monitored to document any changes in the plant community and to identify conditions that could potentially require remedial action to maintain a viable vegetation cover on site.

Precipitation from July 1, 2008, through June 30, 2009, was greater than last year; the total rainfall for this period was 7.44 inches. Soil moisture content data showed that the UC-1 CMP cover is performing as designed, and evapotranspiration is effectively removing water from the cover.

The inspection at UC-3 indicated that the site is in good condition. All monuments and signs showed no displacement or damage, and none have been removed. No other issues or concerns were identified.

The inspection at UC-4 indicated that the site is in good condition. All monuments and signs showed no displacement or damage, and none have been removed. 
This page intentionally left blank 


\subsection{Introduction}

This report presents data collected during the annual post-closure site inspection conducted by the U.S. Department of Energy (DOE) Office of Legacy Management (LM) at the Central Nevada Test Area (CNTA) surface Corrective Action Unit (CAU) 417. This report has been prepared in accordance with the Post-Closure Monitoring Plan contained in the CAU 417 Closure Report (NNSA/NV 2001) and Federal Facility Agreement and Consent Order (FFACO) (FFACO 1996). Responsibility for environmental site restoration of the CNTA was transferred from the DOE Office of Environmental Management to LM on October 1, 2006.

This report provides an analysis and summary of the annual site inspection and subsidence survey, meteorological information, vegetation survey, and soil moisture monitoring data collected since the last annual inspection in May 2008. In 2009, the annual site inspection was conducted to document the physical condition of the CAU 417 soil covers, monuments, signs, fencing, and restricted-use areas. Subsidence surveys of the UC-1 Central Mud Pit (CMP) and UC-4 Mud Pit C covers were also conducted. In addition, the UC-1 CMP cover is instrumented to monitor the soil moisture conditions within the upper 1.2 meters $(\mathrm{m})$ ( 4 feet $[\mathrm{ft}]$ ) of the cover to determine if the cover is performing as designed. Also part of the 2009 inspection was the biennial vegetation survey.

\subsection{Purpose}

The purpose of the post-closure monitoring at CAU 417 is to determine if:

- Maintenance or repairs to the UC-1 CMP or UC-4 Mud Pit C cover, fences, or diversion channels are needed;

- $\quad$ UC-1 CMP or UC-4 Mud Pit C covers are subsiding;

- UC-1 CMP cover is performing as designed;

- Vegetation on the UC-1 CMP cover is healthy;

- Maintenance and repair to the aboveground monuments or warning signs at UC-1, UC-3, and UC-4 are needed; and

- $\quad$ Modifications to the administrative controls are needed.

\subsection{Site Location and Background}

The CNTA is approximately 22.5 kilometers $(\mathrm{km})(14$ miles [mi]) north of U.S. Highway 6 and approximately $137 \mathrm{~km}(85 \mathrm{mi})$ northeast of Tonopah in Nye County, Nevada (Figure 1-1). Three emplacement boreholes, UC-1, UC-3, and UC-4, were drilled at CNTA for underground nuclear weapons testing. On January 19, 1968, the Project Faultless underground nuclear test was

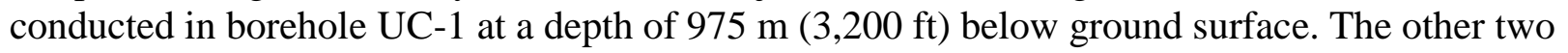
emplacement boreholes (UC-3 and UC-4) were not used, and no further testing was conducted at CNTA. Boreholes UC-1, UC-3, and UC-4 are located on three separate land withdrawals that range in size from approximately 1 to 1.5 square mi (Figure 1-2). All three land withdrawals are accessible to the public. 


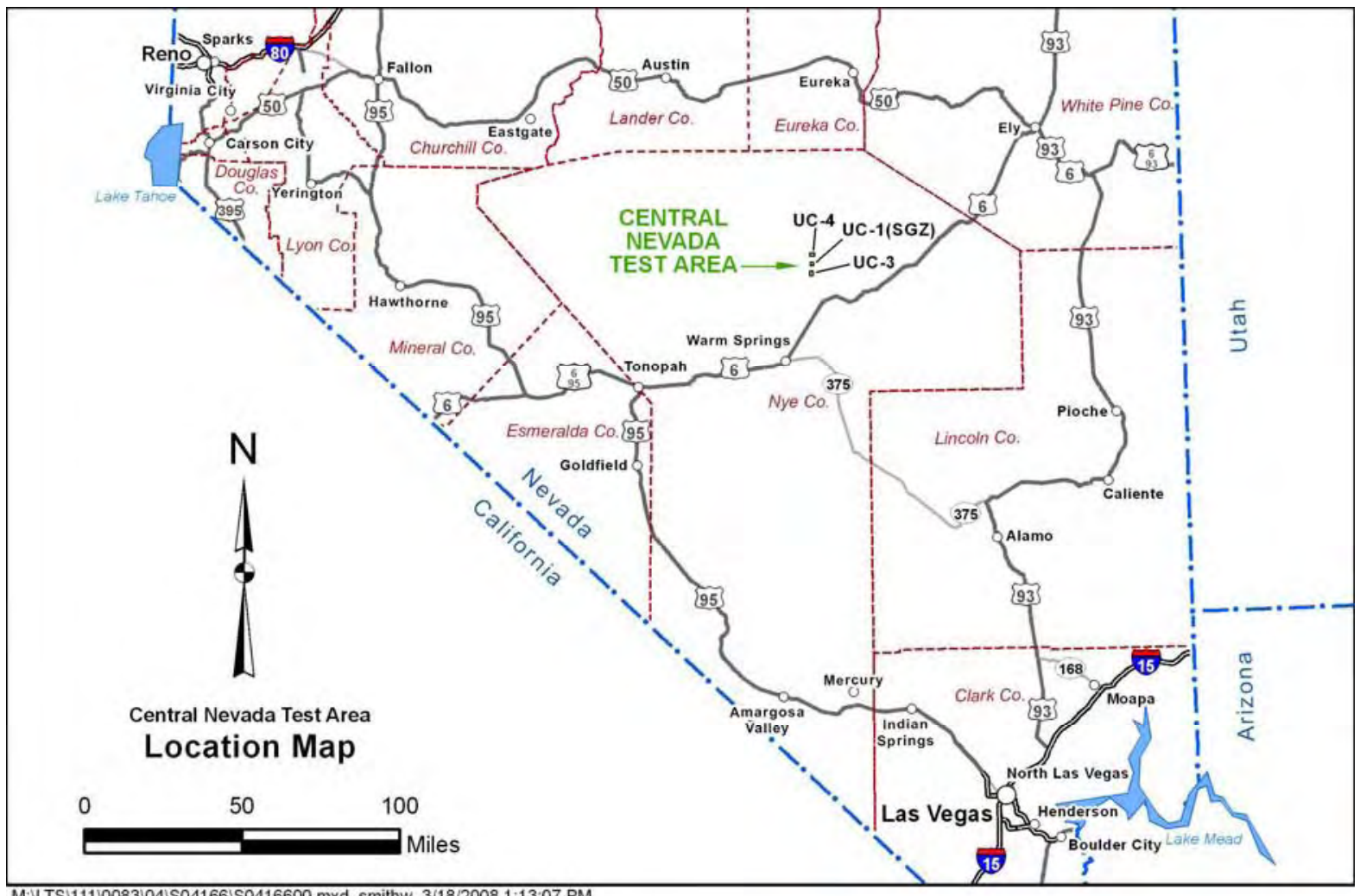

M:LTSI1110083104IS04166IS0416600.mxd smithw 3/18/2008 1:13:07 PM

Figure 1-1. Central Nevada Test Area Location Map

\subsection{Geologic Setting}

The CNTA is in the north-central portion of the Hot Creek Valley within the Basin and Range physiographic province. This province consists of regularly spaced, roughly north-south-trending mountain ranges, separated by alluvial valleys formed by faulting. The UC-1 site lies at an elevation of 1,860 m (6,100 ft) above mean sea level and is bordered by the Hot Creek Range to the west and the Pancake Range to the east. The Hot Creek Range is composed of Paleozoic sedimentary rocks and Tertiary volcanic rocks. The Paleozoic rocks consist of sandstone, quartzite, limestone, and dolomite, and the Tertiary volcanic rocks consist of welded tuff, nonwelded bedded tuff, argillized and zeolitized tuff, conglomeratic tuffaceous sandstone, carbonaceous siltstone, and rhyolite (Healey 1968). The alluvium at UC-1 is approximately $730 \mathrm{~m}(2,400 \mathrm{ft})$ thick and is underlain by tuffaceous sediments and zeolitized tuffs to a depth of

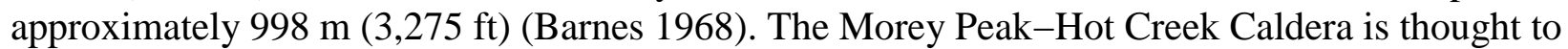
be buried by deposits of tuff and alluvium beneath the northern portion of Hot Creek Valley (Healey 1968).

The Project Faultless test resulted in the subsidence of an irregularly shaped area of approximately 1.5 square kilometer (0.6 square mile). One northeast-trending fault scarp extends beneath the southeastern corner of the UC-1 Mud Pit and cover, with as much as $4.6 \mathrm{~m}$ (15 ft) vertical displacement. Normal drainage patterns were disrupted by the formation of this scarp, so flood diversion channels were constructed to protect the cover and prevent infiltration along the fault scarp (NNSA/NV 2001). The depth to water at the UC-1 CMP is approximately $84 \mathrm{~m}$ (275 ft) bgs based on measurements obtained from well UC-1-P-1S prior to and after its 
recompletion in June 2009 (Figure 1-2). Water levels measured before the recompletion of UC-1-P-1S had been suspect due to difficulties encountered during its drilling and construction in 1968. Historically, the reported depth to water of $550 \mathrm{ft}$ bgs at the CMP was based on measurements obtained from well HTH-2. Well HTH-2 is outside the down-drop graben block, nearly 1,500 ft southwest of the CMP. Well UC-1-P-1S is inside the down-drop graben block less than $200 \mathrm{ft}$ west of the CMP. The differing depths to water inside and outside the graben block (northwest and southeast of the southeast bounding fault) were confirmed by the 2009 drilling program. Wells MV-4 and MV-5 drilled through the southeast graben fault and were dual completions with a piezometer inside the graben and a well outside the graben. The depth to water of the piezometers is consistent with that of well UC-1-P-1S, approximately $275 \mathrm{ft}$ bgs. The depth to water of the wells is consistent with that of well HTH-2, approximately $550 \mathrm{ft}$ bgs. Well HTH-1 (outside the graben block) was also recompleted in 2009 with two piezometers (upper and lower alluvial aquifer) and a well (upper volcanic section). The depth to water of both HTH-1 piezometers is approximately $550 \mathrm{ft}$ bgs. 


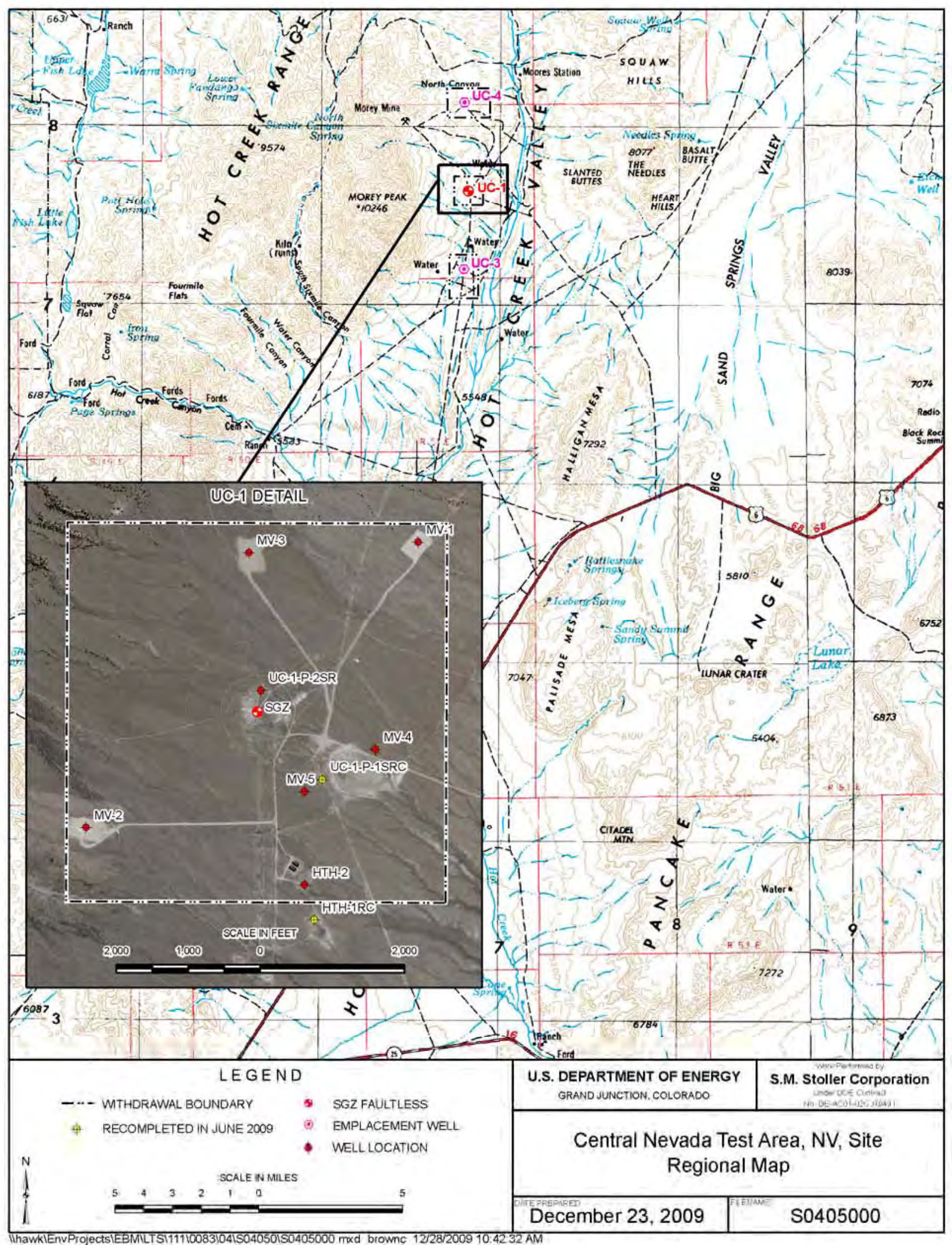

Figure 1-2. CAU 417, Central Nevada Test Area Surface Map 


\subsection{Post-Closure Monitoring Requirements}

\subsection{Site Inspections}

Quarterly inspections have been conducted since closure of the site in 2000. Beginning in 2007, post-closure inspections of CAU 417 have been performed annually. The annual site inspection is documented on an inspection checklist, with site photographs and, if applicable, field notes. The post-closure inspection consists of the following:

- $\quad$ Inspecting the UC-1 CMP cover and UC-4 Mud Pit C cover and fencing. This includes walking the entire perimeter of the fence and documenting the condition of the barbed wire and chicken wire fencing, warning signs, and entrance gate.

- Inspecting all aboveground monuments, attached warning signs, and affixed survey pins placed at UC-1, UC-3, and UC-4 sites for signs of wear, disturbance, vandalism, animal burrows, and other damage. Repairing monuments and attached signs during site inspections or, if necessary, at a later time in the calendar year.

- Inspecting the condition of the 2 subsidence monuments (SMs) on the UC-4 cover and 12 SMs on the UC-1 CMP cover. A subsidence survey of all SMs is conducted annually to determine if the covers have subsided.

- Documenting any changes to the cover or fenced area, including but not limited to, the presence of trash and debris inside the fenced areas, animal burrows on the cover or under the perimeter fence, erosion features on the covers or diversion channels, and any change in the health of the UC-1 CMP cover vegetation.

- Documenting the soil water content profile of the UC-1 CMP cover to evaluate whether it is performing as designed.

- $\quad$ Biennially reporting on the health and stability of the UC-1 CMP cover vegetation.

\subsection{Maintenance and Repair}

If a site inspection detects that either the UC-1 CMP cover or the UC-4 Mud Pit C cover is not in compliance, or if conditions requiring major repairs are noted, or if any other problems in critical areas are noted, then issues will be evaluated and reported to the Nevada Division of Environmental Protection (NDEP) within 60 days of detection (in compliance with the FFACO). The following guidelines apply to CAU 417 maintenance and repairs:

- Cracks, settling features, erosion rills, and animal burrows larger than 15 centimeters $(\mathrm{cm})$ (6 inches) deep that extend $1 \mathrm{~m}$ (3 ft) or more and that do not compromise the UC-1 CMP or UC-4 Mud Pit C covers will be evaluated and repaired within 90 days of detection.

- Noncritical cracks, settling features, erosion rills, and animal burrows less than $15 \mathrm{~cm}$

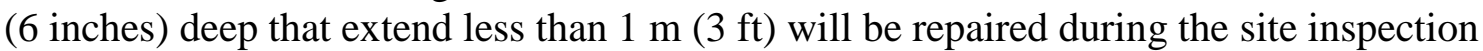
visit.

- Damage to the fencing surrounding the UC-1 CMP cover or the UC-4 Mud Pit C cover, warning signs, or monuments will be evaluated and repaired within 90 days of detection. 
- Major damage to use-restriction warning signs or monuments will be evaluated and repaired during subsequent site inspections.

- All repair work will preserve the original as-built design and will be documented in the annual post-closure report.

\subsection{Cover Moisture Monitoring}

The CNTA UC-1 CMP monolayer cover is designed to limit infiltration of moisture into the disposal unit by evapotranspiration from vegetation that was established on the cover. The cover performance is monitored using time domain reflectometry (TDR) sensor data to provide a profile of the water content in the cover. The soil water content profile determines whether the cover is performing as designed and if it is in compliance with the closure plan and agreements.

The soil moisture content is obtained using a Campbell Scientific TDR-100, recorded by a Campbell Scientific data logger, CR1000, and a radio housed in an instrument vault located just off the southern edge of the cover. The radio transmits data to an on-site telemetry station. Soil moisture data are being recorded twice daily and imported and saved into the System Operation and Analysis at Remote Sites (SOARS) system at LM's Grand Junction office. The postprocessing software used by SOARS automatically produces graphs, creates tables, and backs up data daily.

TDR sensors were buried in the cover at two locations (West TDR and East TDR) during cover construction. At both locations, two TDR sensors were placed below the surface of the cover at the following depths: $0.15,0.46,0.76$, and $1.07 \mathrm{~m}(0.5,1.5,2.5$, and $3.5 \mathrm{ft})$ (Figure 2-1). The TDR nests are located approximately $48 \mathrm{~m}(157 \mathrm{ft})$ northwest and $48 \mathrm{~m}(157 \mathrm{ft})$ northeast of the instrument vault.

The TDR probes were calibrated to volumetric moisture content (VMC) using a dry-down method with native soil and full-length cable. The results of the calibration indicated that a site-specific calibration equation should be used instead of the standard Topp equation (Topp et al. 1980). It was also found that long cable lengths and soil conductivities caused the TDR reflection end points to become extremely flat under saturated and near-saturated conditions, resulting in unreliable data in these regions.

A fourth-order polynomial fit of the calibration data, over the range of 5 to 35 percent VMC, yielded the following calibration equation:

$\operatorname{VMC}(\%)=-308.701+373.1803(\mathrm{~L} / \mathrm{L})-163.644(\mathrm{~L} / \mathrm{L})^{2}+31.82972(\mathrm{~L} / \mathrm{L})^{3}-2.25548(\mathrm{~L} / \mathrm{L})^{4}$

Where $\mathrm{L} / \mathrm{L}$ is the ratio of cable length to probe length as recorded by the data logger.

\subsection{Cover Moisture Compliance Criteria}

The depth of the deepest TDR soil moisture probe is the point of compliance for the UC-1 CMP cover, which is approximately $1.07 \mathrm{~m}(3.5 \mathrm{ft})$ below ground surface. Cover compliance will be based on the soil moisture content of the cover once steady-state conditions are reached. Cover performance modeling presented in the CAU 417 Corrective Action Plan (DOE/NV 2000) predicted that steady-state conditions will be achieved within 10 years of cover construction, which was completed in September of 2000. At that time, it is expected that soil moisture trigger values will be agreed upon as compliance criteria with NDEP. 


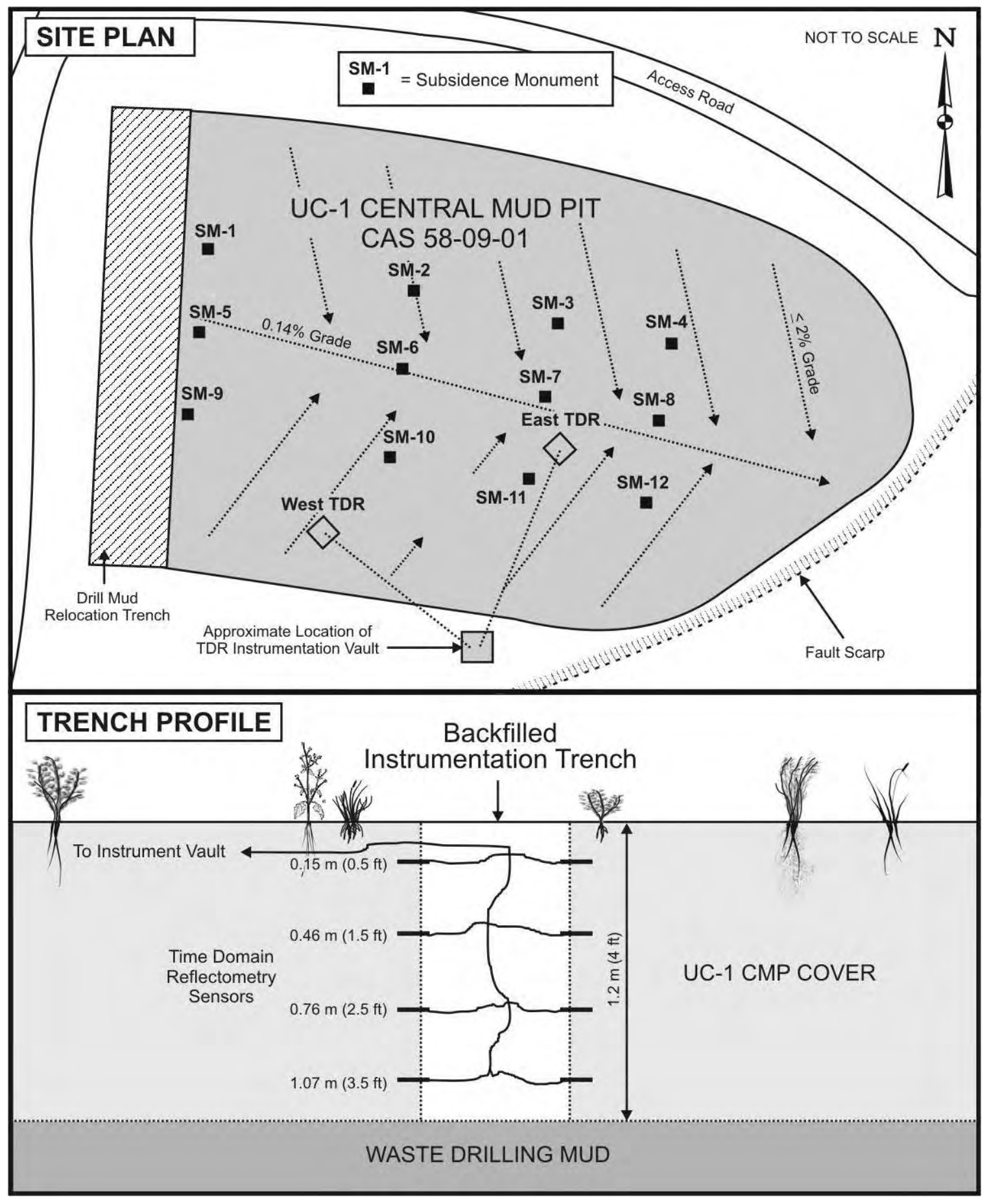

Figure 2-1. UC-1 CMP Cover Monitoring Instrumentation

If soil moisture data indicate that the cover is not operating according to established compliance criteria, NDEP will be notified of the noncompliance within 14 days. After notification of noncompliance, LM will submit a work plan to NDEP within 90 days; the work plan will outline the proposed remediation/investigation plan. All corrective actions will be documented in the annual Post-Closure Inspection and Monitoring Report. 


\subsection{Reporting Requirements}

All inspection and maintenance activities conducted during the year are documented and included in the annual Post-Closure Inspection and Monitoring Report. LM submits the report to NDEP and includes the following information:

- A brief narrative and discussion of all post-closure inspection activities and observations;

- $\quad$ Copies of all completed inspection checklists and maintenance records;

- $\quad$ UC-1 CMP soil moisture content profiles for the current monitoring period;

- $\quad$ Subsidence survey data; and

- Specific recommendations for nonstandard maintenance or changes in post-closure requirements.

All closure and post-closure monitoring documentation is maintained in project files and is available upon request. 


\subsection{Site Inspections, Surveys, and Maintenance}

\subsection{Annual Site Inspection Results}

The annual inspection of the three sites was performed on June 23, 2009. Copies of the inspection checklists and photographs are included in Appendix A. A summary of the inspection results is provided in the following sections.

\subsubsection{UC-1 Inspection}

The locks, fencing, SMs, and signs associated with the CMP were in good order, with the exception of one sign that had fallen along the southeast side of the fence line. Three cracks in the cover showing lateral expansion were observed and repaired at the time of the inspection. The vegetation on the cover continues to look healthy. All other signs and monuments at Mud Pits A and E (Figure 3-1) were in excellent condition.

\subsubsection{UC-3 Inspection}

The site was in excellent condition (Figure 3-2). No issues were identified with the monuments or signs, and no maintenance or repairs were recommended.

\subsubsection{UC-4 Inspection}

The Mud Pit C fence and SMs were in good condition. A pin on the gate lock hasp was missing, but it does not affect the integrity of the locking mechanism. Two small erosion rills were identified at the time of the inspection and repaired. One of the small rills was near the northwest corner, and a slightly more significant rill was near the steeper southwest corner. Mud Pits A, B, and $\mathrm{D}$ were in excellent condition, and no issues were identified with Area S or Area X (Figure 3-3). The overall condition of the site was good; however, some vegetation is growing on the cap. No issues were noted that affected the integrity of the cover and appurtenances.

\subsection{Subsidence Survey Results}

Surveys of the SMs for UC-1 and UC-4 were performed on June 23, 2009. A summary of the survey results is provided in the following sections.

\subsubsection{UC-1 Survey}

Twelve SMs were installed on the UC-1 CMP cover to provide elevation control and measure subsidence of the cover and relocation trench (NNSA/NV 2001). These SMs are shown in Figure 2-1. The baseline subsidence survey was completed on December 4, 2000, and is used as the reference to calculate subsidence for each subsequent survey. Beginning in 2007, annual subsidence monitoring replaced the biannual subsidence monitoring that had taken place since 2002. The UC-1 baseline survey locations and elevations are provided in Appendix B, Table 1 and are presented in graphical form in Figure 3-4. 


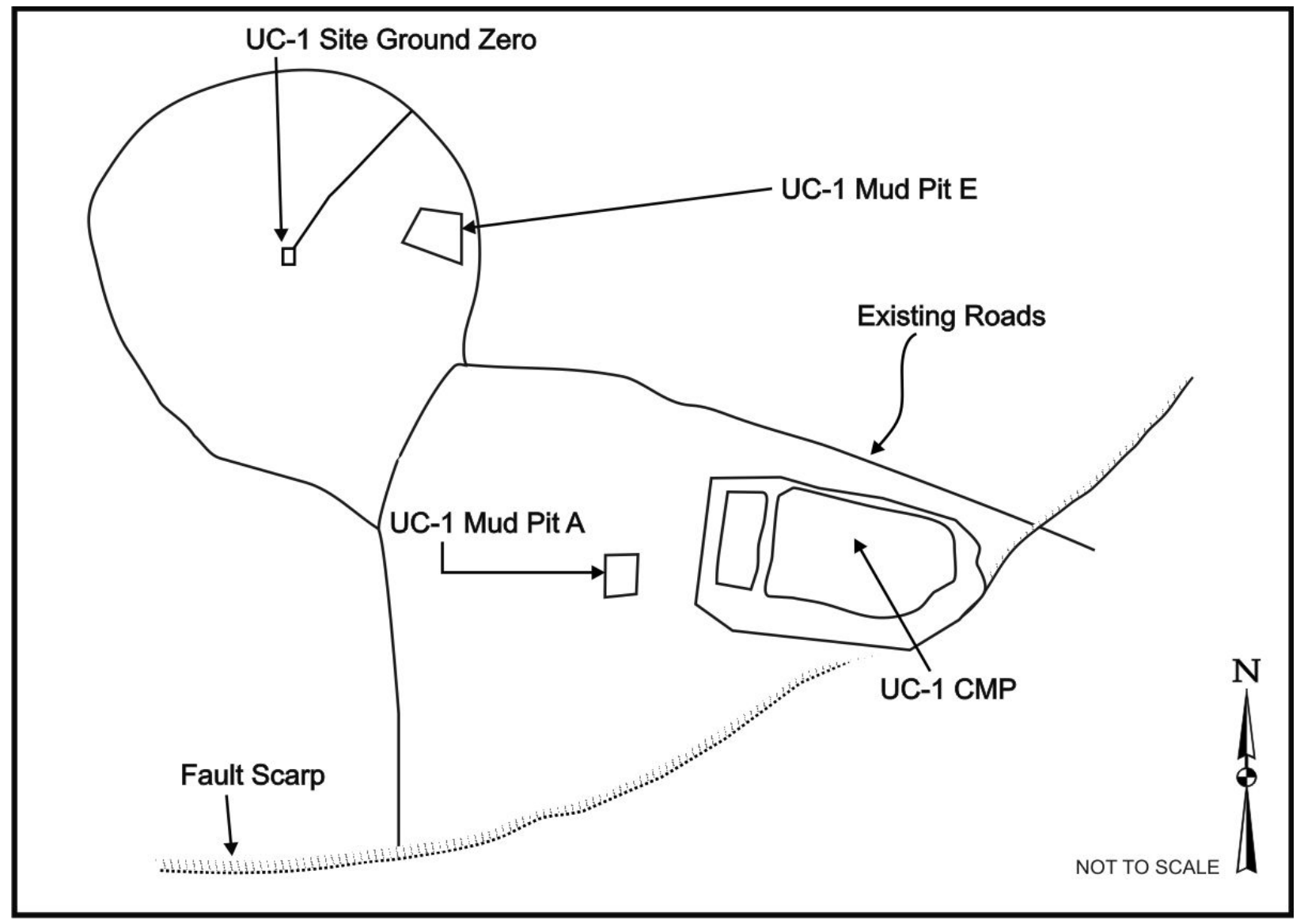

Figure 3-1. Location of UC-1 Significant Features

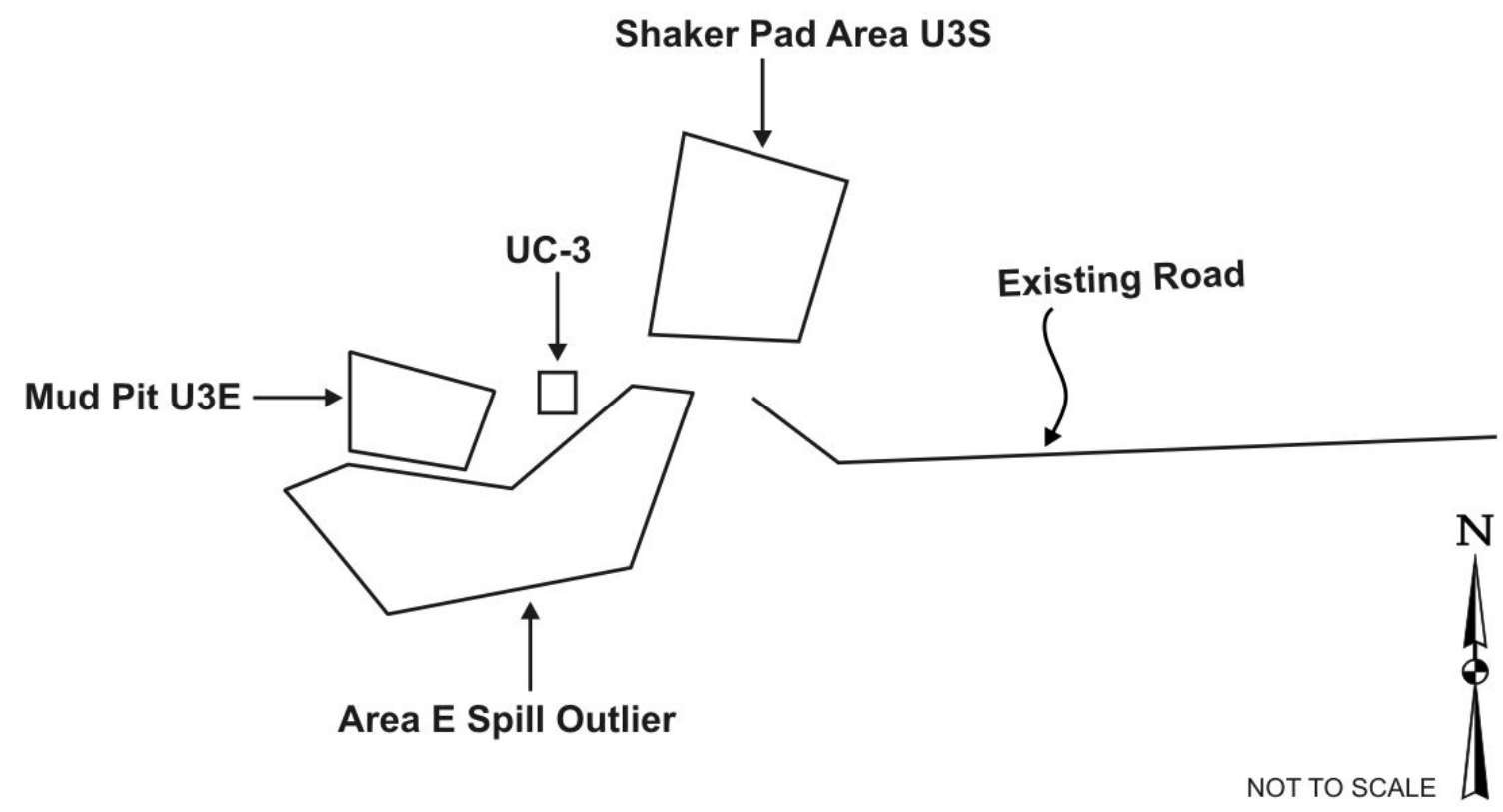

Figure 3-2. Location of UC-3 Significant Features 


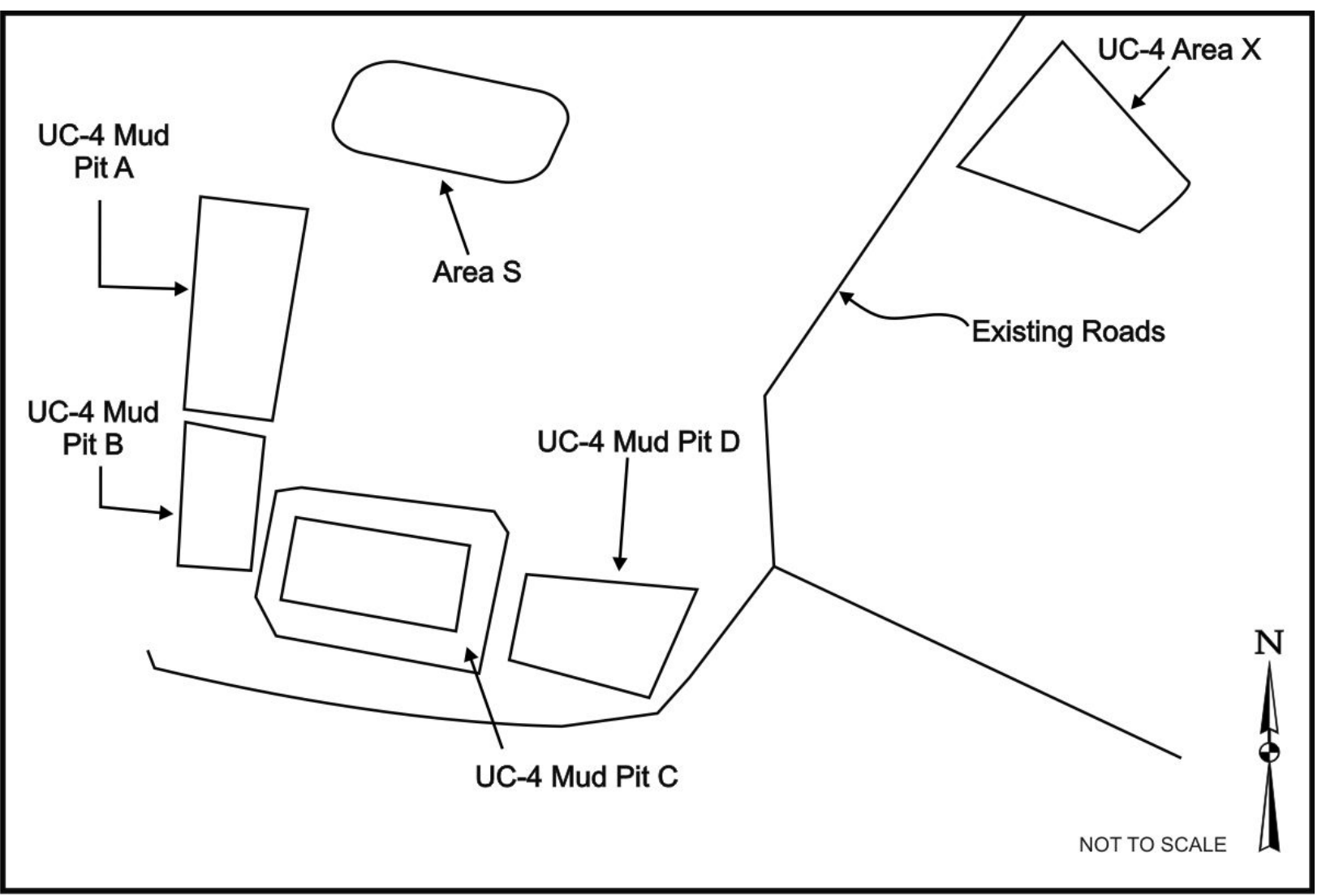

Figure 3-3. Location of UC-4 Significant Features

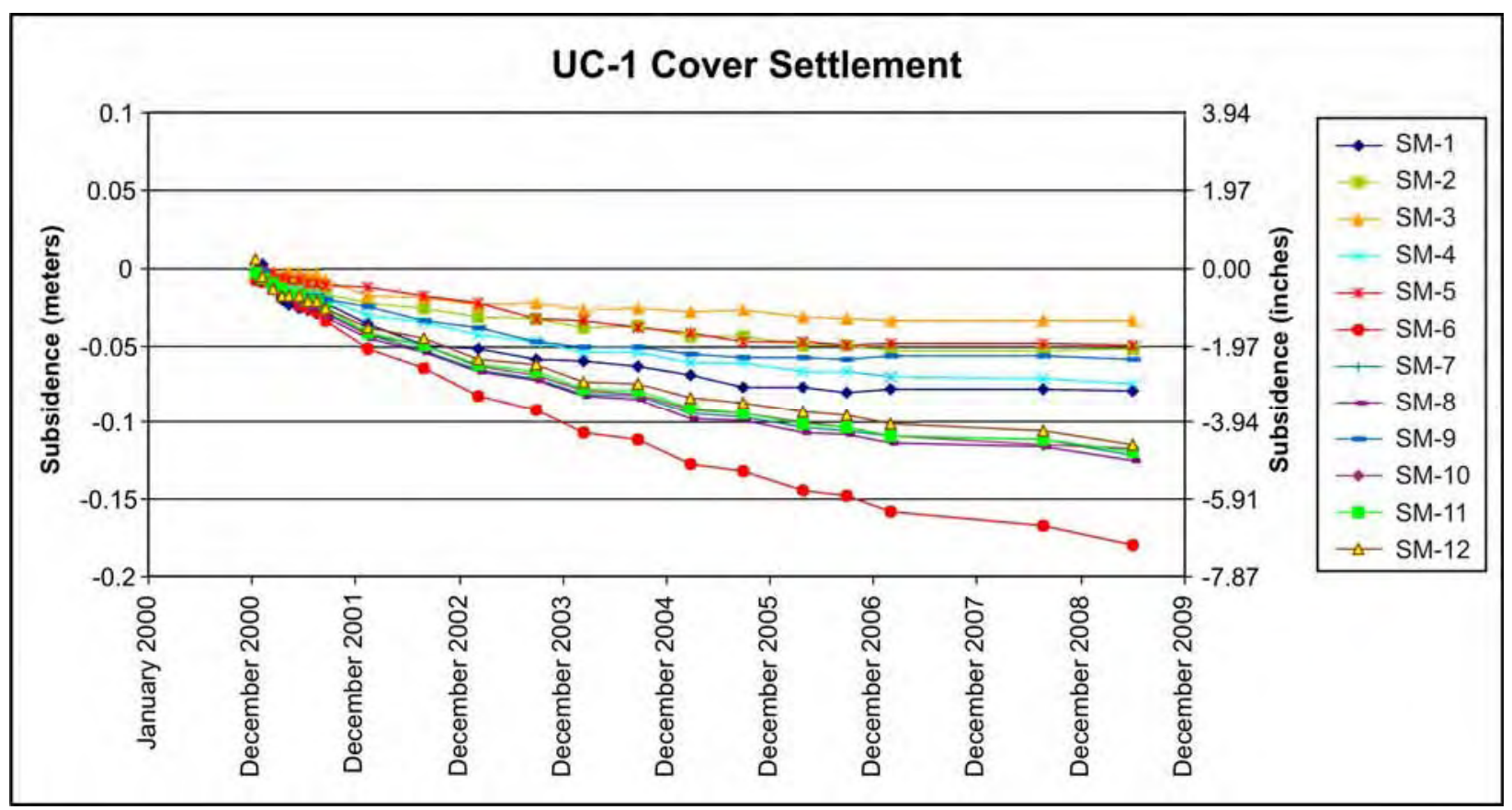

Figure 3-4. UC-1 Cover Settlement 
The degree of settlement in the relocation trench and CMP is within the predicted range and shows no unusual subsidence. The data collected over the CMP section of the cover indicate that the largest subsidence is along the centerline of the CMP, including SM-6, SM-7, and SM-8 and along the southern portion of the cap at SM-10, SM-11, and SM-12. This was expected because of the thicker layer of underlying mud in these areas. The northern monuments SM-2, SM-3, and SM-4, along with the westernmost monuments, SM-1, SM-5 and SM-9, show the least subsidence because of the thinner layer of underlying mud along these margins of the cover. The greatest degree of settlement continues to be on SM-6, which has subsided a total of $0.179 \mathrm{~m}$ (7.05 inches) since the baseline survey in December 2000.

\subsubsection{UC-4 Survey}

Two SMs (west and east monuments) were installed in the UC-4 cover to provide elevation control for measuring the subsidence of the cover. These SMs are shown in Figure 3-5. The baseline subsidence survey was completed on October 12,1999, and is used as the reference survey to calculate subsidence. The UC-4 baseline survey locations and elevations are provided in Appendix B, Table 2 and are presented in graphical form in Figure 3-6. Since the last subsidence survey in 2008, both subsidence markers showed increases in elevation ranging from $0.010 \mathrm{~m}$ (0.39 inches) to $0.013 \mathrm{~m}$ (0.51 inches) from the east and west SMs, respectively. Settling of the west SM is still slightly greater than the predicted settling of $5 \mathrm{~cm}$ (2 inches); the total subsidence is $0.051 \mathrm{~m}$ (2.01 inches) since the baseline survey in October 1999. The east SM has subsided a total of $0.017 \mathrm{~m}$ (0.67 inches) since the baseline survey. The largest changes occurred within the first year.

\subsection{Vegetation Survey Results}

The vegetation survey was performed concurrently with the site inspection on June 23, 2009. The complete vegetation monitoring report is included in Appendix C. A summary of the vegetation survey is provided in this section.

The UC-1 CMP cover and adjacent unfenced disturbed area were seeded in the fall of 2000. In spring 2001, the soil cover was planted with 5,000 vegetation transplants. Evapotranspiration by the vegetation reduces infiltration and percolation of storm water through the cover. The vegetation also helps reduce erosion of the cover by wind and water by reducing surface velocities.

Post-closure requirements for this site include periodic vegetation surveys to assess the establishment of a healthy and stable vascular plant cover and to monitor its effectiveness. A preliminary evaluation of the site was conducted in July 2001 to confirm germination, and subsequent surveys were conducted in October 2001, March 2002, September 2002, June 2003, June 2004, May 2006, and May 2007 to evaluate the density, diversity, and overall condition of the vegetation. These evaluations demonstrated successful establishment of healthy plant communities and adequate resistance of the plants to cold weather. Seeded vegetation in the adjacent area outside the fence has not done as well as the vegetation on the cover because of animal grazing (See Appendix C).

On the CMP cover, total plant cover averaged 23 percent in 2009. This compares favorably to the 18 percent plant cover average estimated in 2007 . The CMP cover is dominated by a variety 
of shrubs, including sagebrush (whereas the native undisturbed area is dominated by sagebrush). Grass cover on the CMP is somewhat less than that on the native, undisturbed area.

Total vegetative cover in the revegetated areas peripheral to the fenced site averaged 14 percent, which is comparable to the 15 percent plant cover estimated in 2007. As in previous years, the vegetation had been noticeably grazed. The ground was covered in rabbit and antelope/deer scat, and only a trace of grass was found overall.

Revegetation of the CMP cover and perimeter area continues to be considered successful.

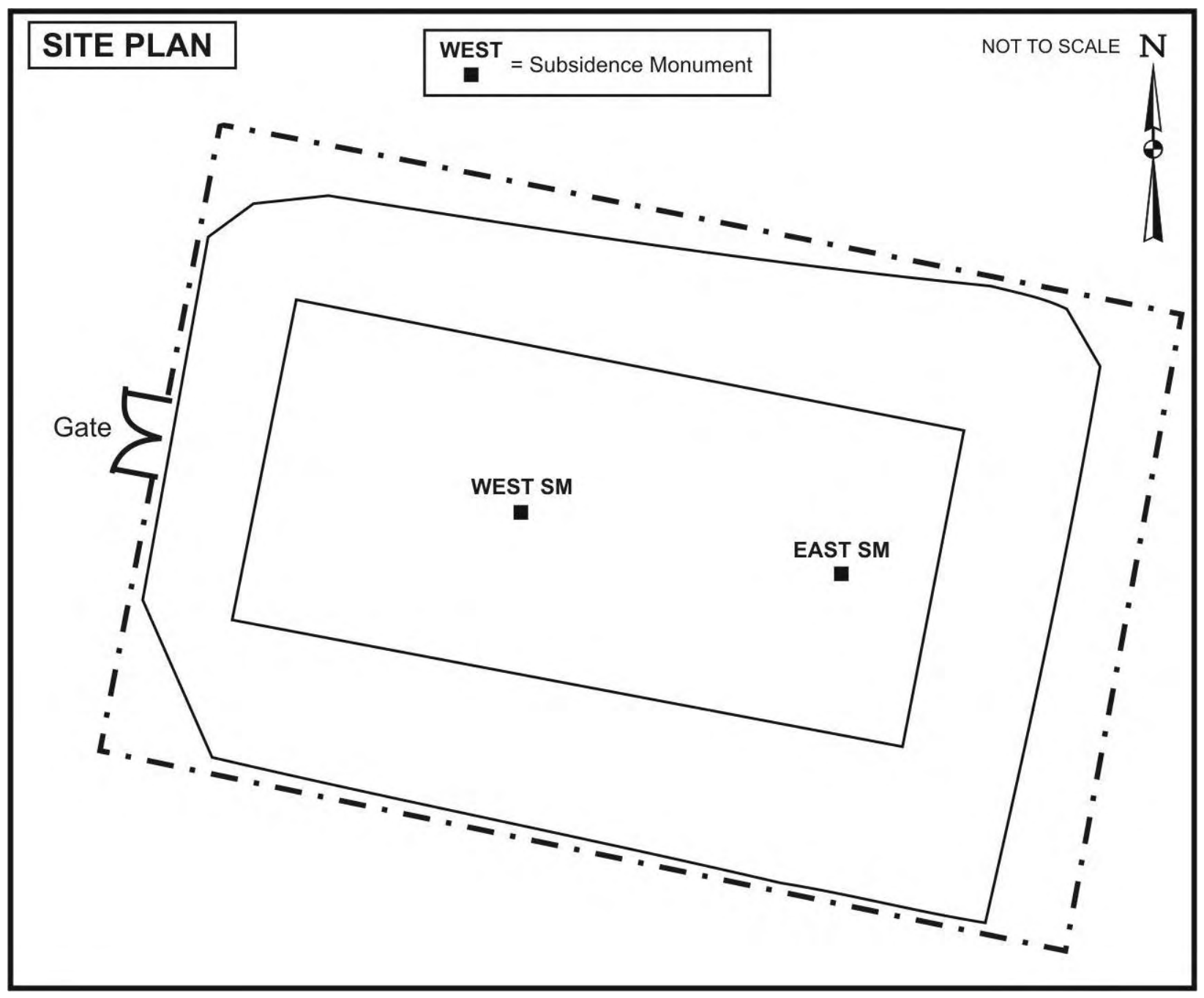

Figure 3-5. UC-4 West and East Monuments 


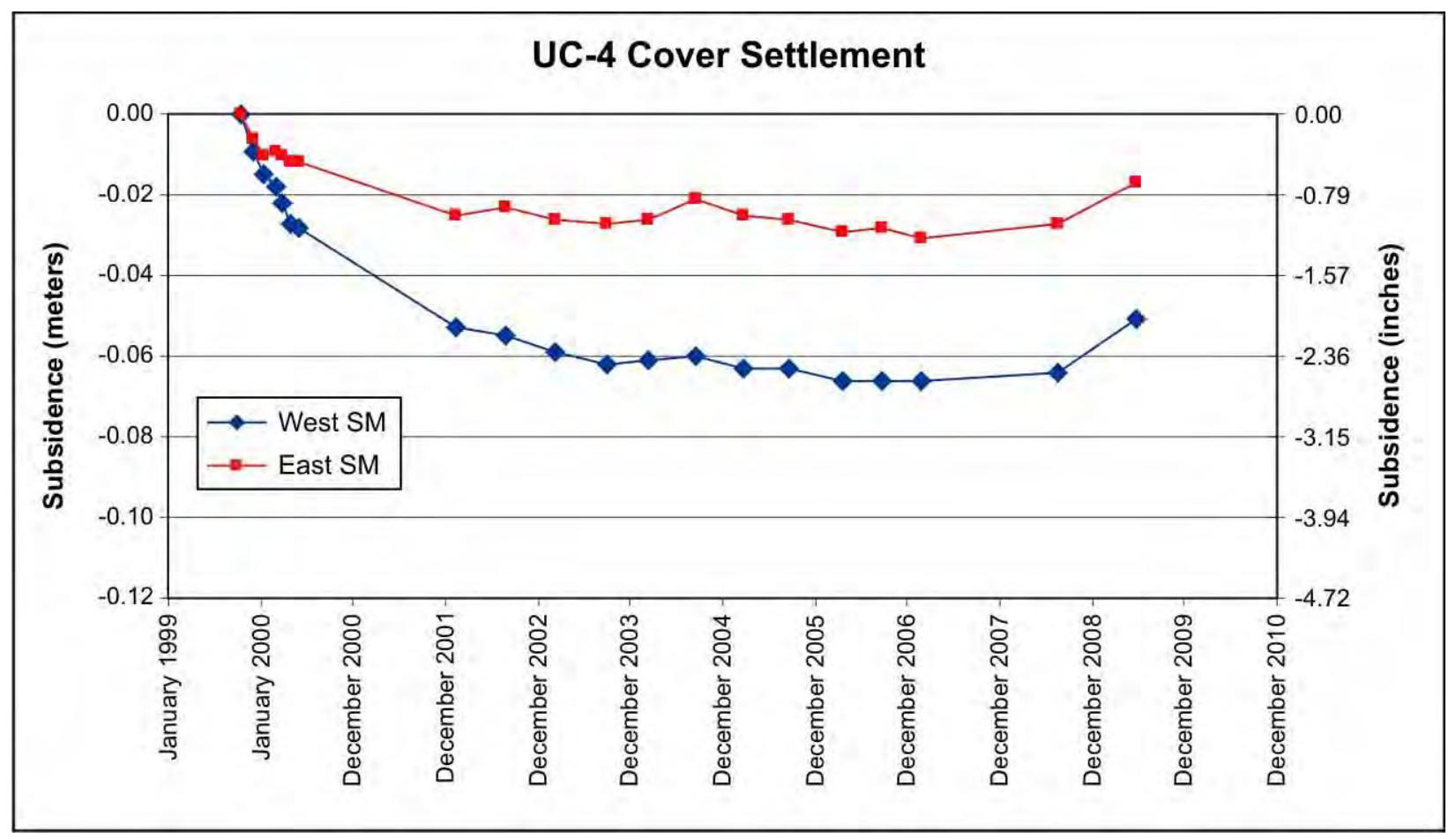

Figure 3-6. UC-4 Cover Settlement

\subsection{Precipitation and Soil Moisture Monitoring Results}

Precipitation data are collected at the UC-1 CMP cover by a Campbell Scientific TE525 tipping bucket rain gauge. A CS705 precipitation adapter is used for snowfall measurements. The rain gauge data are collected and stored by the data logger and sent to an on-site telemetry station where the data are sent and saved to SOARS. The rain gauge was evaluated and repaired during a general site maintenance visit conducted in early October 2008.

The 12-month precipitation record from the UC-1 CMP rain gauge is presented in Figure 3-7. Precipitation measured from July 1, 2008, through June 30, 2009, totaling 188.97 millimeters (7.44 inches).

\subsubsection{UC-1 Soil Moisture Results}

Graphs of the TDR-derived soil moisture content for July 1, 2008, through June 30, 2009, are presented in Figure 3-8 through Figure 3-11. 


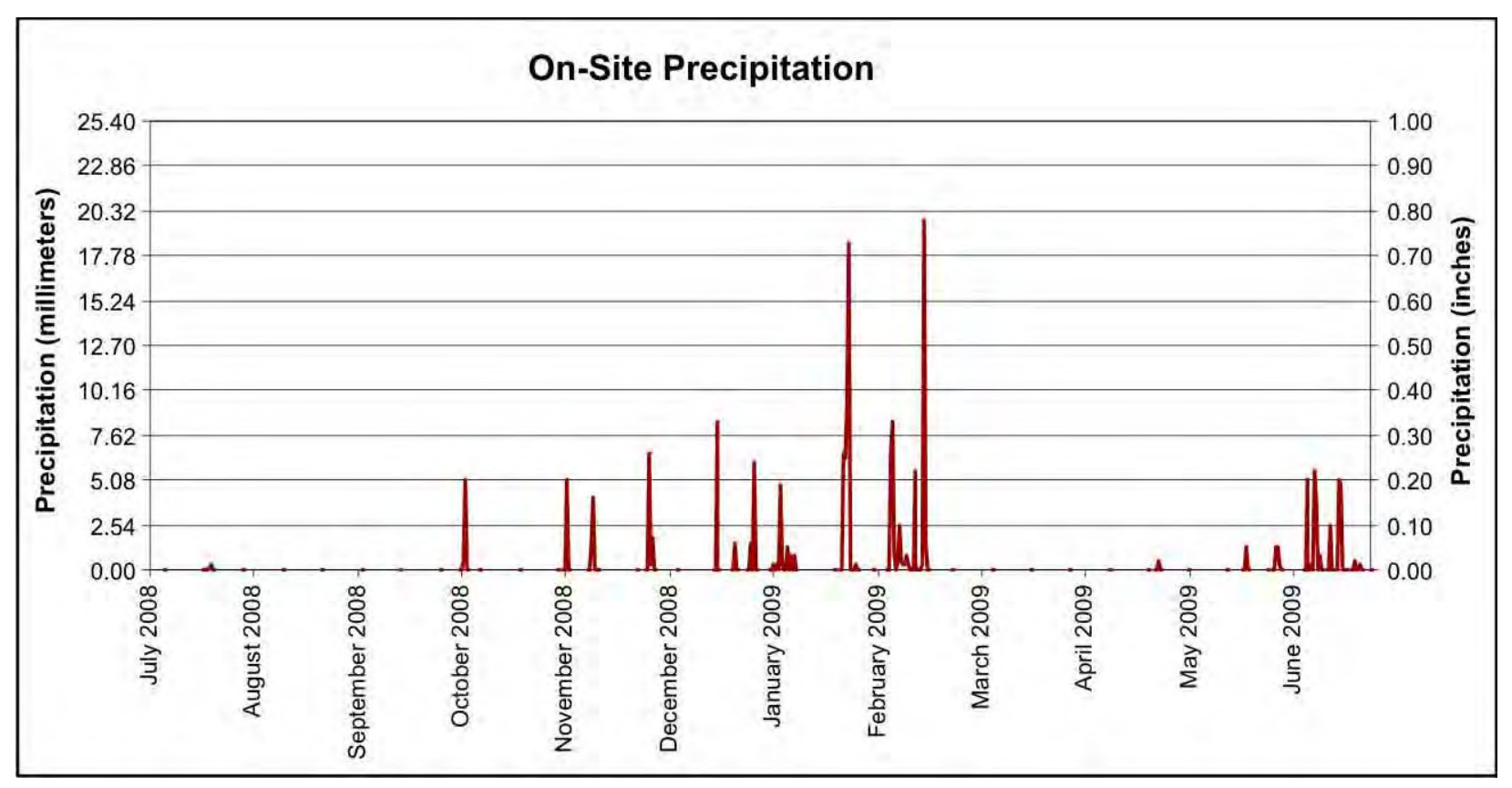

Figure 3-7. July 1, 2008, through June 30, 2009, Precipitation Data

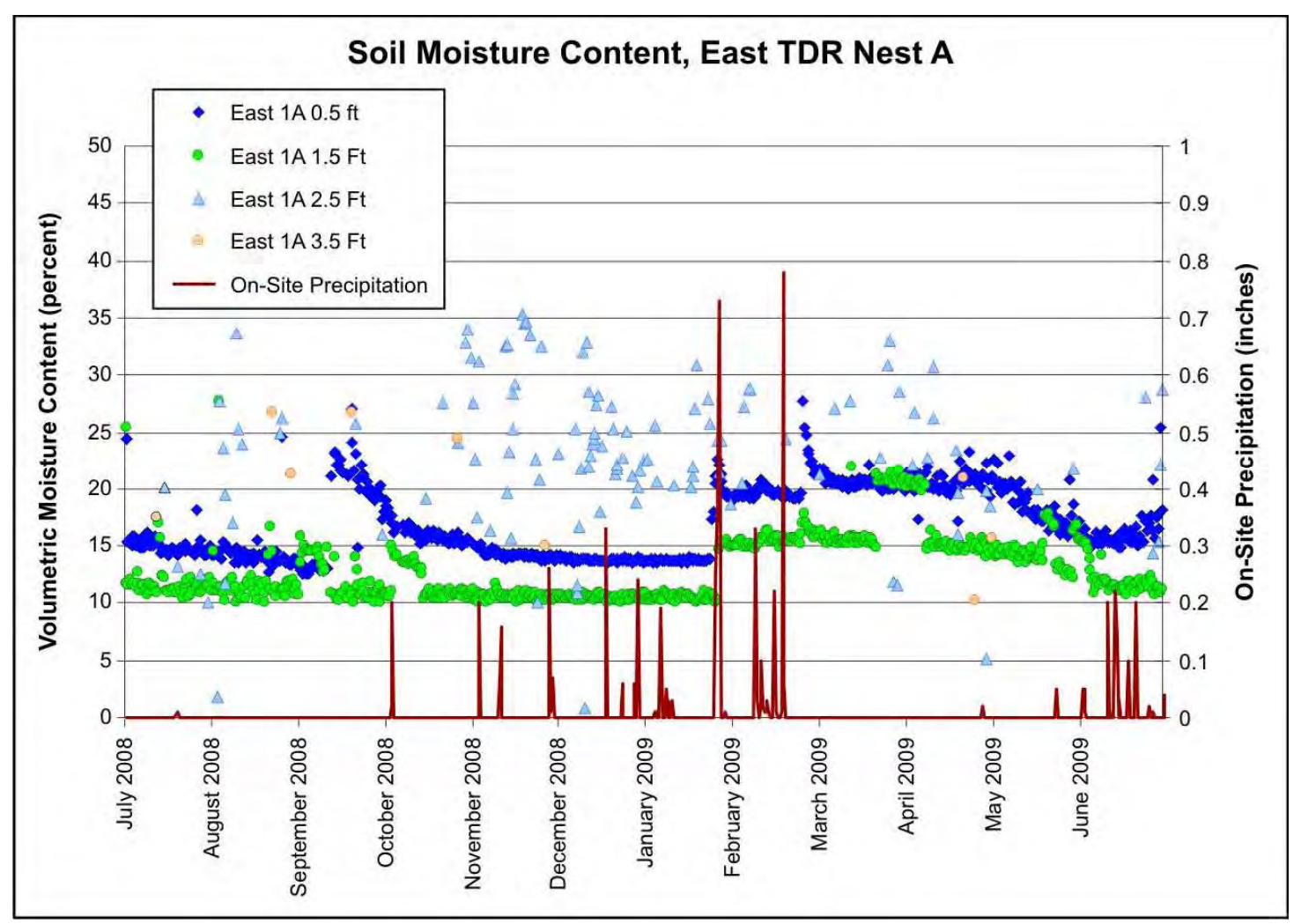

Figure 3-8. UC-1 Soil Moisture Content, East TDR Nest A 


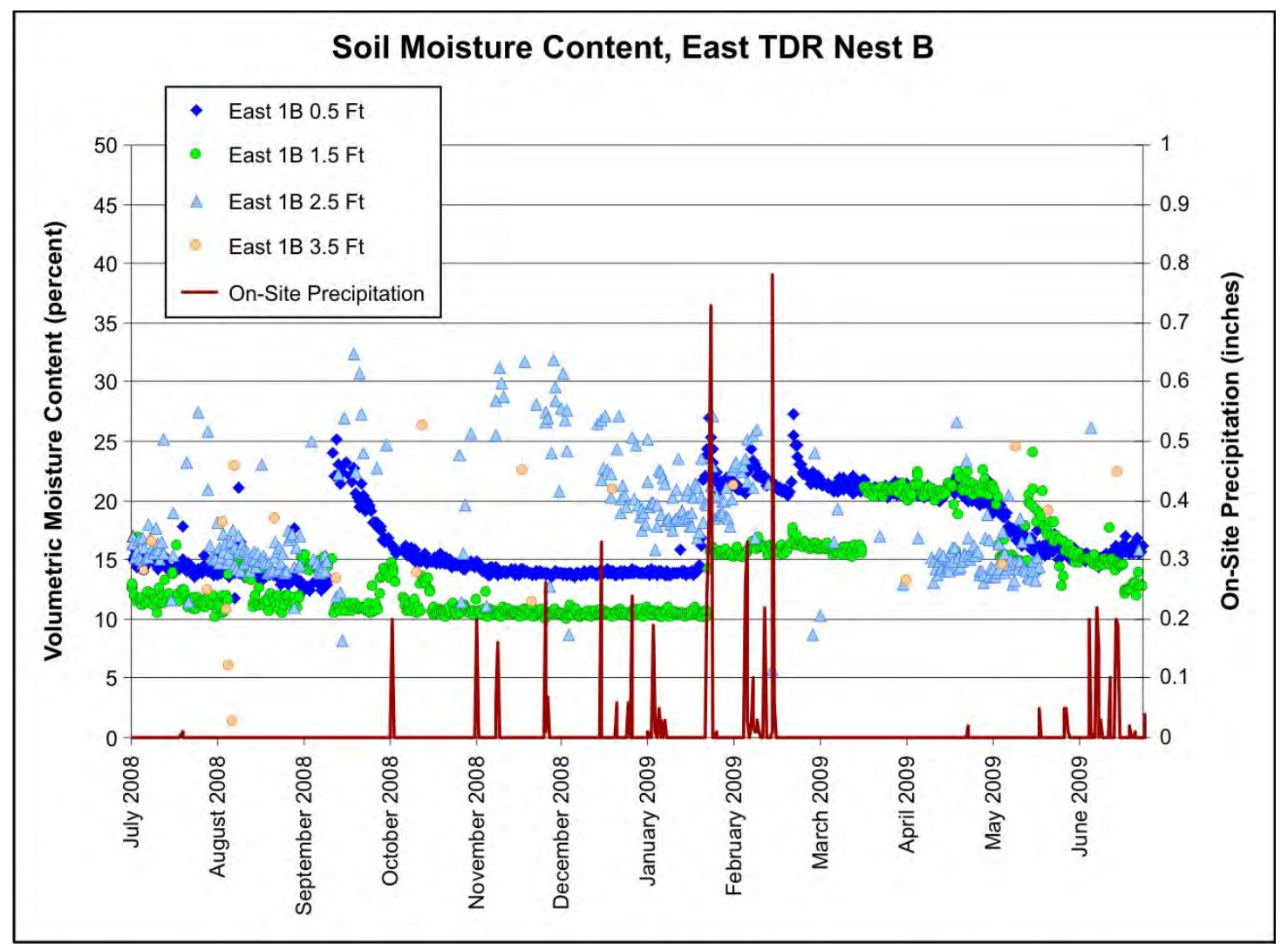

Figure 3-9. UC-1 Soil Moisture Content, East TDR Nest B

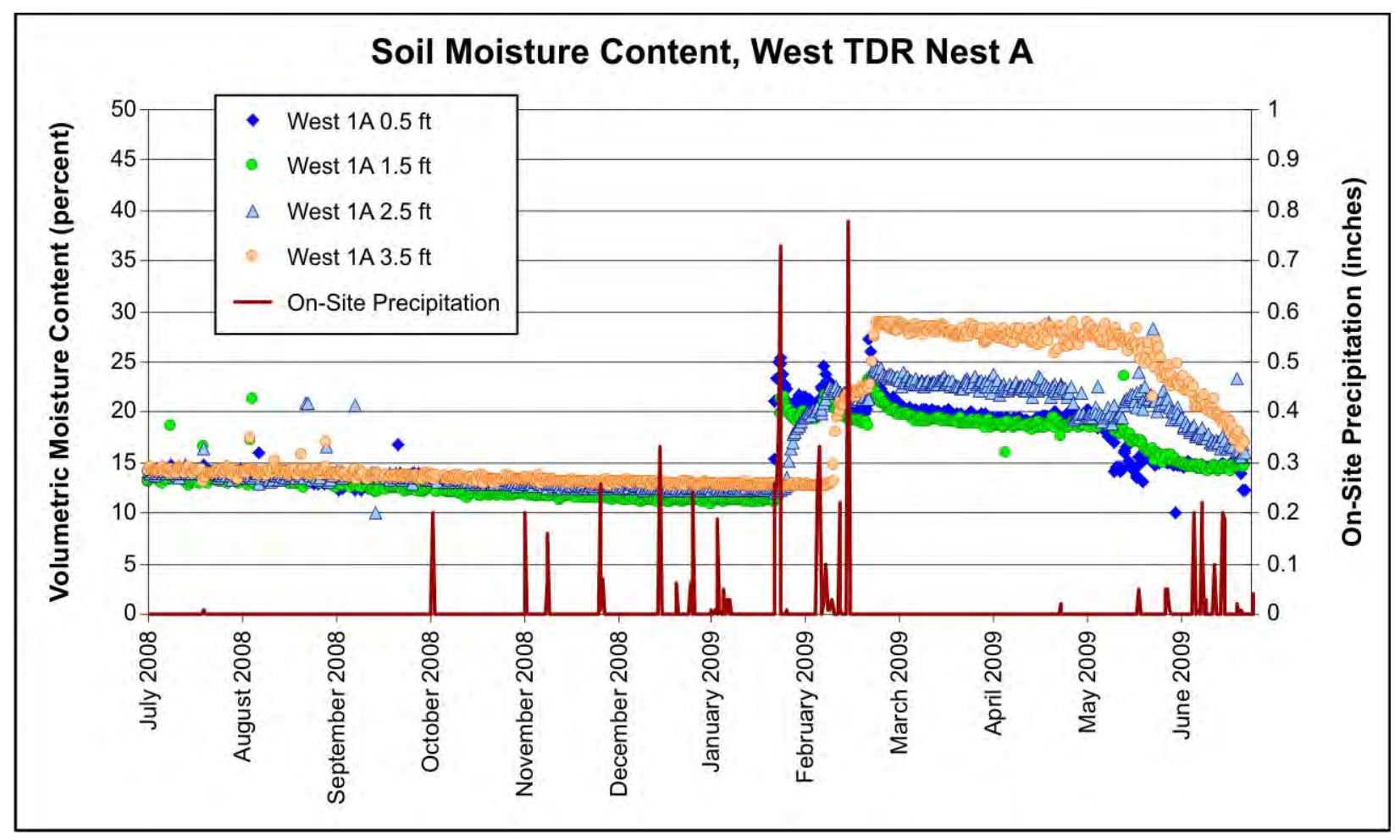

Figure 3-10. UC-1 Soil Moisture Content, West TDR Nest A 


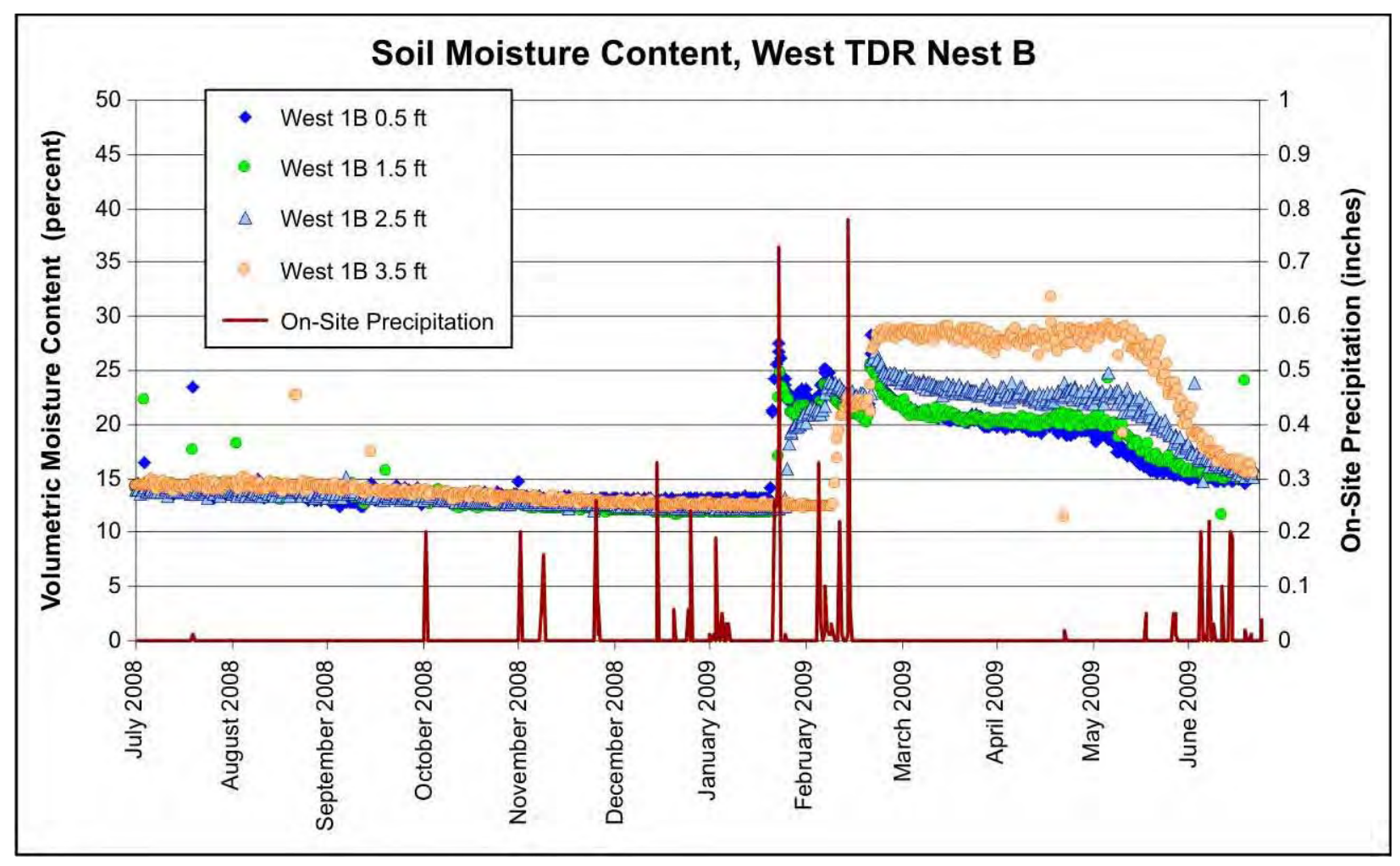

Figure 3-11. UC-1 Soil Moisture Content, West TDR Nest B

\section{UC-1 East TDR Nest}

TDR data obtained for the east nests, measured at depths of $0.76 \mathrm{~m}$ and $1.07 \mathrm{~m}(2.5$ and $3.5 \mathrm{ft})$, were entirely corrupted from an unknown cause. Previously, the lengthy cable created a problem in measuring the reflected signal from the TDR probes (NNSA/NV 2007). Inappropriate signal responses from the two lower stations in the east TDR nest make interpretation of the data difficult. The TDR data from all depths are presented on the respective graphs, but only the two TDR sensors at the shallower depths appear to be responding to the infiltrating moisture. From these data it appears that VMC fluctuates by approximately 5 percent in the upper $1.5 \mathrm{ft}$ of the cap.

\section{UC-1 West TDR Nest}

Moisture content measurements indicate steady-state conditions throughout most of the year with VMC varying by less than one percent in the upper $2.5 \mathrm{ft}$ of the cap. Significant moisture events in late January to early-mid February 2009 sent a slug of moisture through the cover, and VMC varied from 0 to 2 percent down to $1.5 \mathrm{ft}$ and up to approximately 8 percent at depth, $3.5 \mathrm{ft}$. These trends extended into mid-May when surface temperatures increased, and evapotranspiration once again became effective at removing moisture from the cover.

With the exception of the lower two stations in the east TDR, both nests present similar profiles and indicate that the cover is performing as designed, with evapotranspiration effectively removing water from the cover. The moisture content at the two deeper profiles of the west TDR nest appears to be approaching steady-state conditions at between 10 to 15 percent VMC. The moisture sensors in the two deeper profiles of the east TDR nest are not functioning. 
This page intentionally left blank

Post-Closure Inspection \& Monitoring Report for CAU 417

Doc. No. S05767

Page 3-10 


\subsection{Summary, Conclusions, and Recommendations}

\subsection{Summary}

The 2009 annual inspection of UC-1 CMP indicated continued integrity of the cover unit. Three new cracks or fractures were observed on the UC-1 CMP cover during the 2009 annual inspection. These cracks were repaired with an application of bentonite fill at the time of the inspection. No issues were identified with the fence or gate.

The June 2009 vegetation survey indicates that the UC-1 CMP revegetation is performing better than in 2007. The vegetation should continue to be monitored to document any changes in the plant community and identify conditions that could potentially require remedial action in order to maintain a viable vegetation cover on the site. It is suggested that future vegetation surveys be conducted once every 2 years or as needed to help monitor the health of the vegetation.

From July 1, 2008, through June 30, 2009, the rainfall total was 188.97 millimeters (7.44 inches). According to the Western Regional Climate Center of Reno, Nevada, the region surrounding CNTA's location has been experiencing severe drought conditions for the last few years. Soil moisture content data show that the UC-1 cover is performing as designed, and evapotranspiration is effectively removing water from the cover.

The UC-1 settling trend that has been occurring since December 2000 continued to show a slight decrease in cover elevation during the current monitoring period. The degree of settling in both the relocation trench and the CMP is within the predicted range and shows no unusual subsidence.

The inspection of UC-3 indicated that the sites are in excellent condition. All monuments and use-restriction signs are in good condition. No issues were identified, and no maintenance or repair activities are recommended at this time.

The inspection of UC-4 indicated that the sites are in excellent condition. All monuments and use-restriction signs are in good condition. No concerns were identified with the monuments or gate.

In the annual survey, measurements at the UC-4 east monument indicated a slight increase in elevation. Subsidence at the west monument is still slightly greater than the predicted settling; the total subsidence was $6.6 \mathrm{~cm}$ (2.6 inches) since the baseline survey in October 1999. The cause of the increase in elevation of the two UC-4 monuments is unknown.

\subsection{Conclusions}

The following conclusions are based on the 2009 annual inspection:

- $\quad$ No significant concerns were noted for the UC-1 CMP and UC-4 Mud Pit C covers during the annual inspection, and no further maintenance or repairs are recommended at this time.

- No significant concerns were noted on the subsidence surveys for UC-1 and UC-4. The increases in elevation of the UC-4 monuments will be further evaluated during the 2010 annual inspection. 
- With and exception of the lower two stations at the East TDR nest, soil moisture monitoring data indicate that the cover is performing as designed and that evapotranspiration appears to be effectively removing water from the cover.

- The soil moisture monitoring compliance criteria cannot be established at this time because of the regional drought conditions.

\subsection{Recommendations}

The following recommendations are based on the 2009 annual inspection:

- Continue site inspections annually as scheduled to observe the condition of the covers, fence, vegetation, signs, and monuments.

- Continue annual subsidence surveys on UC-1 and UC-4.

- Conduct a vegetation survey in 2011 to comply with the agreement to perform the vegetation survey biennially.

- $\quad$ Remove large vegetation from UC-4 cover during the 2010 inspection.

- Continue soil moisture data collection from the west TDR nest and, when possible, from the east TDR nest.

- $\quad$ Respond to reports from the public of detrimental conditions at the site within 90 days.

- $\quad$ Meet with NDEP after the 2010 annual inspection and report to discuss the closure plan with respect to historical site data collected, present site conditions, repair of the lower two sensors at the East TDR nest, and future path forward. 


\subsection{References}

Barnes, W., 1968. Report of Exploration Progress, Central Nevada, Period August 1, 1967 December 31, 1967, U.S. Geological Survey Technical Letter, Central Nevada 3-2.

DOE/NV (U.S. Department of Energy, Nevada Operations Office), 2000. Corrective Action Plan for Corrective Action Unit 417: Central Nevada Test Area Surface, Nevada, DOE/NV-588, Las Vegas, Nevada.

FFACO (Federal Facility Agreement and Consent Order), 1996 (as amended). Agreed to by the State of Nevada, the U.S. Department of Energy, and the U.S. Department of Defense.

Healey, D.L., 1968. Gravity Survey of Northern Hot Creek Valley, Nye County, Nevada, U.S. Geological Survey Technical Letter, Central Nevada-18.

NNSA/NV (U.S. Department of Energy, National Nuclear Security Administration Nevada Operations Office), 2001. Closure Report for Corrective Action Unit 417: Central Nevada Test Area Surface, Nevada, DOE/NV-743, Rev. 1, Las Vegas, Nevada.

NNSA/NV (U.S. Department of Energy, National Nuclear Security Administration Nevada Operations Office), 2007. Post-Closure Inspection and Monitoring Report for Corrective Action Unit 417: Central Nevada Test Area-Surface Hot Creek Valley, Nevada, DOE/NV/25946-168, Las Vegas, Nevada.

Topp, G.C., Davis, J.L., and Annan, A.P., 1980. "Electromagnetic Determination of Soil Water Content: Measurements in Coaxial Transmission Lines," Water Resources Research, vol. 16, pp. 574-582. 
This page intentionally left blank

Post-Closure Inspection \& Monitoring Report for CAU 417

Doc. No. S05767

U.S. Department of Energy

Page 5-2 